\title{
Letter to the editor: A response to the comments of Pyörälä (2012)
}

\author{
K. Schwaiger, ${ }^{* 1}$ M. Wimmer, ${ }^{*}$ R. Huber-Schlenstedt, † K. Fehlings,† C. S. Hölzel, ${ }^{*}$ and J. Bauer ${ }^{\star}$ \\ ${ }^{*}$ Chair of Animal Hygiene Technische Universität München Weihenstephaner Berg 385354 Freising-Weihenstephan, Germany \\ †Bavarian Animal Health Service (TGD) Senator-Gerauer-Str. 23, 85586 Poing, Germany
}

We appreciate the opportunity to respond to the Letter to the Editor by Pyörälä (2012) in response to our recently published paper "Hot topic: Bovine milk samples yielding negative or nonspecific results in bacterial culturing - The possible role of PCR-single strand conformation polymorphism in mastitis diagnosis" (Schwaiger et al., 2012). According to the instructions to authors of the Journal of Dairy Science, "Hot Topics" are supposed to point to avenues for fruitful, indepth analyses, even if the results may be preliminary in nature. Our paper simply aimed to inform the scientific reader about a new and, in our opinion, promising tool for mastitis diagnosis. The detection of Helcococcus ovis, together with Trueperella pyogenes (formerly Arcanobacterium pyogenes) and Peptoniphilus spp., is an interesting additional and incidental finding, pointing out the diagnostic potential of PCR-single strand conformation polymorphism (PCR-SSCP). Of course, the next step will be to investigate the possible role of $H$. ovis in mastitis by considering clinical aspects, ideally by detecting this bacterium in the diseased udder. Seek and you shall find-but without Schwaiger et al. (2012), no one would think of seeking and hardly anyone would accidentally find this microorganism because of its fastidious growth (Q.E.D: no one has found it in the past).

The article of Braem et al. (2012) indeed provides an interesting insight into the microbial flora in the teat canal. In that study, an unexpectedly wide bacterial diversity was revealed, but $H$. ovis was not detected in 48 samples originating from the teat apices of dairy cows. This is, of course, no proof that $H$. ovis is a mastitis pathogen; nevertheless, the absence of this bacterium in the direct vicinity might indicate that it is not just a widely distributed and ubiquitously occurring contaminant. We agree that the "good old Koch's postulates" should always be borne in mind. However, we reiterate that mastitis is a multifactorial problem. The postulates are not applicable to multi-causal infectious

Received May 14, 2012.

Accepted May 16, 2012.

${ }^{1}$ Corresponding author: Karin.Schwaiger@wzw.tum.de diseases, because these diseases develop from the synergistic interaction of different, normally nonpathogenic processes, which makes the "cause and effect" relationship inapplicable (Jousimies-Somer et al., 1996; Nelson et al., 2012).

Undoubtedly, an aseptic technique in taking milk samples is a prerequisite for meaningful results. We have found that, even for molecular biological purposes, taking samples with negligible contamination is readily achievable, because we found a large number of "clean" milk samples from mastitis-free cattle by PCR-SSCP (data not shown). Unfortunately, but realistically, milk samples absolutely free of contamination cannot be guaranteed in routine sampling, and we think it would be very regrettable if any scientific work were stopped until this problem is solved (which it might never be). In contrast to commercially available PCR tests, the described PCR-SSCP technique does not allow an automatic interpretation. Instead, the informative value for differentiating contaminants from the probable causative agents strongly depends on the experience of the examiner, just as in conventional culture methods.

In any case, the major problem in mastitis diagnosis remains that the causative agent cannot be identified in more than 30\% of milk samples (Taponen et al., 2009). This problem cannot be solved by traditional microbiology because many bacteria are patently nonculturable because of insufficient cultivation technologies (Maccaferri et al., 2011). This problem cannot be solved by conventional or commercially available PCR, because the method is limited to the detection of specifically targeted species using species- or genus-specific primers (Taponen et al., 2009). Because of the preliminary character of our study (Schwaiger et al., 2012), we cannot warrant that the PCR-SSCP method will be the answer to the problem, but we are still working on it, and our latest results suggest that we may be on the right track.

\section{REFERENCES}

Braem, G., S. De Vliegher, B. Verbist, M. Heyndrickx, F. de Leroy, and L. De Vuyst. 2012. Culture-independent exploration of the teat apex microbiota of dairy cows reveals a wide bacterial species diversity. Vet. Microbiol. 157:383-390. 
Jousimies-Somer, H., S. Pyörälä, and A. Kanervo. 1996. Susceptibilities of bovine summer mastitis bacteria to antimicrobial agents. Antimicrob. Agents Chemother. 40:157-160.

Maccaferri, S., E. Biagi, and P. Brigidi. 2011. Metagenomics: Key to human gut microbiota. Dig. Dis. 29:525-530.

Nelson, A., A. De Soyza, J. D. Perry, I. C. Sutcliffe, and S. P. Cummings. 2012. Polymicrobial challenges to Koch's postulates: Ecological lessons from the bacterial vaginosis and cystic fibrosis microbiomes. Innate Immunol. http://dx.doi.org/10.1177/1753425912439910.

Pyörälä, S. 2012. Letter to the editor: Comments on Schwaiger et al. (2012). J. Dairy Sci. 95:4185.
Schwaiger, K., M. Wimmer, R. Huber-Schlenstedt, K. Fehlings, C. S. Hölzel, and J. Bauer. 2012. Hot topic: Bovine milk samples yielding negative or nonspecific results in bacterial culturing - The possible role of PCR-single strand conformation polymorphism in mastitis diagnosis. J. Dairy Sci. 95:98-101.

Taponen, S., L. Salmiviki, H. Simojoki, M. T. Koskinen, and S. Pyörälä. 2009. Realtime polymerase chain reaction-based identification of bacteria in milk samples from bovine clinical mastitis with no growth in conventional culturing. J. Dairy Sci. 92:26102617 . 